\title{
The Jain Ontological Model according to Kundakunda and Umāsvāti
}

\author{
Ana BAJŽELJ*
}

\begin{abstract}
Jainism proposes a unique theory of reality in which the extreme positions of absolute identity and permanence on the one hand and absolute difference and change on the other are avoided in favour of integrative ontology. Here, identity and difference as well as permanence and change are coordinated. The vertical and horizontal descriptions of the nature of reality are reflected in the basic definitions of substance and existence. This paper examines how this ontology is outlined in the works of Kundakunda and Umāsvāti.
\end{abstract}

Keywords: Jainism, ontology, identity, difference, permanence, change

\section{Izvleček}

Džainizem predlaga edinstveno teorijo stvarnosti, ki v prid integrativni ontologiji obide skrajni stališči absolutne identitete in stalnosti na eni strani ter absolutne razlike in spremembe na drugi. Razmerje med identiteto in razliko ter stalnostjo in spremembo je opredeljeno kot koordinativno. Vertikalen in horizontalen opis narave stvarnosti se odražata v temeljnih opredelitvah substance in eksistence. Pričujoči članek preiskuje, kako je navedena ontologija zastavljena v delih Kundakunda in Umāsvātija.

Ključne besede: džainizem, ontologija, identiteta, razlika, stalnost, sprememba

\footnotetext{
* Ana BAJŽELJ, PhD Candidate, Department of Philosophy, Faculty of Arts, University of Ljubljana, Slovenia. anabajzelj1@gmail.com
} 
This paper will investigate the Jain ontological ${ }^{1}$ model, which is frequently referred to as an identity-in-difference and a permanence-in-change view of reality. In the course of outlining the Jain ontological position, the texts of two philosophers, namely Kundakunda and Umāsvāti, will be predominantly addressed. This choice rests on the fact that these two figures pioneered the systematization of Jain doctrine, explicating the basic tenets of Jain philosophy. The main texts consulted will be Kundakunda's Pañcāstikāyasāra (Pks), Pravacanasāra (Ps), Samayasāra $(S s)$ and Niyamasāra $(N s),{ }^{2}$ as well as Umāsvāti's Tattvārthasūtra ${ }^{3}$ $(T s) .{ }^{4}$ After drafting the general ontology of Kundakunda and Umāsvāti, this article will examine their basic definitions of existence and substance as well as critically analyse the relation between the two. Next, two ways of studying substance will be attended to, namely vertical (non-temporal) and horizontal (temporal). Through this a comprehensive model of reality according to early systematizations of Jain thought will be summarized.

The Jain ontological model is unique in the context of Indian philosophies in so far as it refuses to agree with any of the absolute ontological positions. It repudiates the ontological positions advocating reality to be characterized by absolute identity in which difference is reduced to relative and secondary levels of reality. It similarly declines the ontological notions of absolute permanence which discard change as illusory. ${ }^{5}$ Additionally, Jain philosophers disagree with the ontologies of absolute difference which refute all relations of identity. They likewise oppose ontological stances of absolute change which pronounce permanence to be merely a secondary and artificial conception. ${ }^{6}$ Jainism instead adopts an intermediary approach, synthesizing the extreme ontological positions of absolute identity/permanence and absolute difference/change. Taking into account all of the four above-mentioned features of reality, Jainism, moreover, rejects the

\footnotetext{
${ }^{1}$ The term ontology is employed in the broad sense of a theory of "what there is" (cf. Matilal 1977, 92). The term reality will be used here in the same way.

${ }^{2}$ Kundakunda's texts are composed in a Prākrit, which Richard Pischel (1849-1908), a German Indologist, termed "Jaina Śaurasenī." Within the text, this article will employ the Sanskrit rendition of the Prākrit terms. The Prākrit originals will be quoted in the footnotes to Kundakunda's gāthās.

${ }^{3}$ Also known as Tattvārthādigamasūtra. Umāsvāti compiled this text in Sanskrit, thus establishing a dialogue with the other contemporary Indian traditions and their doctrinal expositions in the sütra form.

${ }^{4}$ In the footnotes to direct quotations from these four sources, the original text will be provided. Unless stated otherwise, all translations are the author's.

${ }^{5}$ In the context of Indian philosophico-religious traditions, the ontological positions of absolute identity and absolute permanence are supported by various non-dualist (Skt. advaita) schools of thought.

${ }^{6}$ Both of the latter views are proposed by various Buddhist schools.
} 
subordination of any one of these aspects of reality to the other, ${ }^{7}$ maintaining the relationship between the identical/permanent and the different/changing aspects of reality to be coordinated (Padmarajiah 1963, 123). None of the ontological features is therefore considered to be primary. Hence, what exists must be permanent, yet changing at the same time. Also, identity as well as difference may be recognized between various aspects of individual existents in time.

In order to further clarify these four aspects of reality and their coordinative relationship, a preliminary examination of what it actually means "to be" or "to exist" for a Jain philosopher is required. The Jain ontological terminology referring to being or existence is commonly derived from the verbal root ${\sqrt{a s}-{ }^{8}}^{8}$ the meaning of which is "to be," "to exist" or "to be present." A frequently used nominal derivative that will be discussed in this paper is sat. With reference to the verbal meaning, it may be translated as existence. What is existence according to Kundakunda and Umāsvāti? In Sas $5.29^{10}$ Umāsvāti refers to existence (Skt. sat) with regard to substance (Skt. dravya). The sütra ("saddravyalakșaṇam") may be grammatically interpreted in two different ways. ${ }^{11}$ The compound dravyalaksanam may be understood as a bahuvrihi, describing existence (Skt. sat). In line with this, Umāsvāti would be maintaining that existence is that of which the mark (Skt. lakșana) is substance (Skt. dravya). In other words, existence is marked by substance. This interpretation corresponds to the Bimal Krishna Matilal's translation of the sütra as "What there is, has the nature of substance" (Matilal 1977, 99). More commonly, however, the compound dravyalaksanam is understood as a simple genitive tatpurușa. According to this interpretation, Umāsvāti defines existence as the mark of substance, implying that substance is something which exists. This understanding agrees with Nathmal Tatia's translation of the sūtra as "Existence is the character of a substance" (Umāsvāti 2011, 135) (cf. Ps I.18, II.5-6, II.13). Both possible grammatical analyses seem to describe an ontological picture which proposes the existence of a substance or several substances. According to the first interpretation, everything that exists is

\footnotetext{
${ }^{7}$ As opposed to, for example, the views of sāmkhya and viśiștādvaita-vedānta.

${ }^{8} \mathrm{~A}$ great portion of nominal derivatives employed for Indian ontological discourse is also derived from the verbal root $\sqrt{ } b h \bar{u}$ - "to be."

${ }^{9}$ In his introduction to basic ontological terms of Indian philosophy, Wilhelm Halbfass, however, remarks that "[b]oth $b h \bar{u}$ and as have more prominent existential and veridical functions than to be; $b h \bar{u}$ has, moreover, dynamic implications" (Halbfass 1992, 22). The latter function is clearly indicated in the Sanskrit word for truth, namely satya.

10 The reference is from a Digambara commentary to Umāsvāti's Tattvārthasūtra called Sarvārthasiddhi, compiled by Pūjyapāda.

${ }^{11}$ The author would like to thank Chris Haskett for the helpful suggestions with these interpretations.
} 
marked by substance. This implies that existence is necessarily indicated or expressed by substance, either one or many. According to the second interpretation, existence characterizes substance, meaning that a singular substance or a plurality of them exists. One need not at once opt for one of the two interpretations. Their (in)compatibility will be explicated once the qualitative and quantitative aspects of substance(s) as well as its/their place in the broader map of reality proposed by Kundakunda and Umāsvāti are brought to light.

The term dravya here therefore proves to be a key concept for the understanding of the Jain theory of what there is, and, as will be demonstrated, of the coordinated relationship between both identity and difference as well as permanence and change in Jain ontology. In examining the nature of substance, two ways of looking at it need to be considered. One is its general non-temporal structure, i.e. its complete vertical cross-section. The other is its temporary character, i.e. its horizontal cross-section. The first will describe its principal components as well as illustrate a comprehensive picture of reality, namely the number of substances, their (dis)similarities and relation to one another. The second will reveal how substance functions in time and thereby explain the place of identity and difference as well as permanence and change in the proposed structure of reality.

Umāsvāti defines substance through its relation to attribute (Skt. guna) and mode (Skt. paryāya): "Substance possesses attribute(s) and mode(s)"12 (Ts 5.37). By defining substance as possessing attribute(s) and mode(s), Umāsvāti presents the reader with three different relations, namely one between substance and attribute, one between substance and mode and one between attribute and mode. In the context of Jain thought, the general relation between substance on the one hand and attribute(s) and mode(s) on the other is not to be understood as one of subordination, i.e. substance does not ontologically precede attribute(s) and mode(s) which it is maintained to possess. It does not possess attribute(s) and mode(s) as substance would possess accidental predicates, while retaining its being independent of their existence. Regarding the relationship between substance, attribute and mode, Kundakunda states in gāthās 12 and 13 of Pañcāstikāyasāra that substance would no longer be substance without the other two, hence defining attribute and mode as inherent and indispensable features of substance. Additionally, he claims this dependence to be mutual. "Substance is not

\footnotetext{
${ }^{12}$ gunaparyāyavaddravyam / This definition is reminiscent of Vaiśeșika-sūtra I.1.15, which defines substance as possessing action(s) and attribute(s) (Skt. kriyagunavat).
} 
deprived of mode(s) nor are modes detached from substance(s). The being of both is not without the other, so expound the śramanas."13 "Attributes are not without substance, substance is not found without attributes. Therefore, the nature of substance and attributes is non-separate." ${ }^{14}$ Hence, the non-temporal relation between substance on the one hand and attribute(s) and mode(s) on the other is not merely accidental, but essential. In that sense, they are said to be non-separate. Apart from indicating the relationship between substance, attribute and mode, these two $g \bar{a} t h \bar{a}$ s additionally establish the plurality of attributes and modes. In the case of attributes $P k s 13$ discloses that a single substance is related to a plurality of attributes. From the point of view of an individual substance, the substance is therefore one, although it is simultaneously manifold from the view-point of the many attributes it possesses. In the case of modes, such relation is not yet clarified, even though a plurality of modes is spoken of in $P k s 12$. Moreover, the number of substances has not yet been ascertained.

Even though Kundakunda establishes the relationship between the relata discussed as one of coordination (i.e. one is not subordinated to the other) and mutual dependence (i.e. there is no substance without attributes/modes and vice versa), this does not entail that they are identical to one another nor that the nature of the two sides of the relation is the same. The three aspects remain nonexclusively distinct and substance is not to attribute what attribute is to substance (cf. PS II.16), additionally, substance is not to mode what mode is to substance. To expand on this, the individual relationships outlined above need to be examined.

The first relationship is one between substance and a plurality of attributes. According to Umāsvāti, substance functions as a support (Skt. āśraya) for attributes. This means that attributes are established owing to the fact that substance provides the footing for them. However, attributes cannot perform the same supportive function as substance since that would render them substances as well. "Attributes are those the foundation of which is [of/by] substance (and) which are without attribute(s)" "15 (Ts 5.40). As far as the relation of attributes towards substance goes, Kundakunda claims that substances are “ $\ldots$ described (as) having the character of attribute(s) ..."16 (Ps II.1). Substance therefore functions as

\footnotetext{
${ }^{13}$ pajjayavijudam davvam davvavijuttā ya pajjayā natthi / doṇham aṇaṇabhūdam bhāvam samanāa parūvemti // (cf. Ps I.10, II.18).

${ }^{14}$ davvena viṇa ṇa guṇā guṇehim davvam vinā ṇa sambhavadi / avvadiritto bhāvo davvaguṇānam havadi tamhā //

${ }_{16}^{15}$ dravyāśrayā nirguñā guṇāh /

16 ... guṇappagaṇi bhaṇidāni / ...
} 
a base for a number of attributes, which in turn characterize it. In addition to explaining the relationship between substance and attribute, this gāth $\bar{a}$ (indirectly) refers to a plurality of substances. This means that the Jain ontological model proposes numerous substances which are characterized by several attributes and each of which is essentially related to at least one mode. In Jainism, attributes are generally understood to function as essential factors by which a certain substance is differentiated from the ones belonging to another substantial genus. ${ }^{17}$ Through the characterizing function of attributes, a relation of relative identity or relative difference may be recognized between various substances. Substances with different attributes are considered to belong to different classes of substances (cf. Ss 103). Substances of the same genus share the same attributes and from that view-point they are matching. Nonetheless, substances from the same class are not completely identical to one another. They are merely corresponding from the point of view of attributes which are, as will be demonstrated by the temporal model of substances, co-extensive with substances.

Now it is possible to account for the difference between substances in so far as they belong to distinct genera. However, the following gāth $\bar{a}$ from Kundakunda, speaks of the difference on another level: "Regarding the object of substance, every substance is non-different. However, regarding the object of its mode(s), (every substance) is different ..." ${ }^{\prime 18}$ (Ps II.22). To begin with, this gāthā speaks of non-difference between substances. However, this non-difference is not to be understood in the sense that has just been considered, i.e. in the sense of likeness between substances belonging to the same genus, but more generally, namely nondifference in so far as they are substances. The gāth $\bar{a}$ continues by referring to a distinction between substances. Not only are substances different as far as they belong to groups characterized by different attributes, they are different as individual substances in so far as they possess distinct modes. ${ }^{19}$ The factor which functions as differentia for distinguishing substances within the same genus is their mode. In other words, mode is that particular aspect of substance that presents its differentiating factor. But what is substance to its mode(s)?

\footnotetext{
${ }^{17}$ This will be further clarified once particular substances proposed by Kundakunda and Umāsvāti are examined.

${ }^{18}$ davvațthieṇa savvam davvam tạ pajjayațthieṇa guṇo / havadi ya aṇnamanaṇnam ... //

${ }^{19}$ Jayandra Soni points out that within Jainism the term guna developed later than paryaya, perhaps both for the reason of outlining a complete and precise ontological model as well as due to the influence of the Nyāya-Vaiśeșika system which operated with the term (Soni 1991, 75, cf. Upadhye 1984, 63).
} 
Kundakunda holds: “... [S]ubstance is the substratum of attributes and mode(s) ..."20 (PS I.87). Substances are then not only the foundation for attributes but also the ground for mode(s). The ontological model elaborated so far therefore consists of substances supporting attributes and mode(s), which respectively provide them with general and specific qualifications. All substances are nondifferent from each other as far as they are substances. Based on the attributes they possess, they may be classified into various groups. Within particular groups they may be further distinguished by specific modes they support. The number of modes as particular manifestations of substances will be clarified once the temporal picture of substances is presented.

The last relation to be explicated is the one between attributes and modes. Similarly to what has been said for the relation between substance on the one hand and attributes and mode(s) on the other, likewise attributes are not to modes what modes are to attributes. Attributes on the one hand act as formative domains within which modes can manifest themselves. Modes on the other hand offer particular manifestations of general attributes. This will be better illustrated by bringing particular substances into discussion.

Substances are said to be infinite in number (cf. Ps I.49). Apart from a class containing sentient substances (Skt. jīva), Kundakunda and Umāsvāti speak of five ${ }^{21}$ classes of insentient (Skt. ajīva) substances. "Substance is living (and) nonliving. The living is, furthermore, constituted of the application of consciousness. The non-living is non-conscious and the foremost (of it) is matter",22 (PS II.35). Among insentient substances matter (Skt. pudgala) is insentient and material, whereas space (Skt. $\bar{a} k \bar{a} s \dot{s}$ ), the medium of motion (skt. dharma), the medium of rest (Skt. adharma) and time (Skt. kāla) are insentient and immaterial. In the words of Kundakunda: "Living substances, extensive substances of matter, the medium of motion, the medium of rest, space and time, conjoined with various attributes and mode(s), are said to be the principles" ${ }^{23}$ (NS 9). As implied above, all of these substances are non-different to the extent of being substances.

\footnotetext{
20 ... gunapajjayānạm appā davva ... // (cf. Ps II.9).

${ }^{21}$ It ought to be pointed out that whereas Digambaras accept time as a separate substance, Śvetāmbaras are divided regarding the inclusion of time in the list of substances (cf. Ts 5.38, Sas 5.39).

${ }^{22}$ davvam jīvamajīvam jīvo puṇa cedaṇovajogamao / poggaladavvappamuham acedaṇam havadi ajjīiạn //

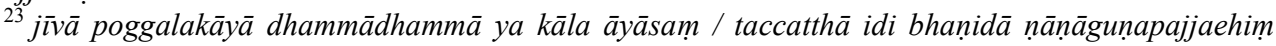
samjutta // Although not clearly indicated in this gāth $\bar{a}$, the substance of time is considered to be the only non-extensive substance.
} 
However, the essential attributes they possess are the criteria for classifying them into various genera of substances. In the words of Kundakunda: "The features by which the living and non-living substance are discerned, are to be known as concrete and non-concrete atributes, particular to their nature" ${ }^{24}$ (PS II.38). For example, all the substances in the genus of sentient substances possess innumerable non-concrete attributes, the basic ones of which are consciousness (Skt. caitanya), bliss (Skt. sukha) and energy (Skt. virya). These attributes differ from the essential attributes of each of the non-sentient substances. The sentient substances may also be differentiated from one another, that is, by the modes they possess. In the case of sentient substances and their attributes, a specific mode is the degree to which one of its essential attributes is manifested. For example, sentient substances vary according to different manifestations of their attribute of consciousness.

So far, a rudimentary picture of Jain ontology has been constructed. While the relationship between substance and existence remains to be clarified, the structure of substance in its vertical dimension has been demonstrated by explicating the nature of relations between substance and its aspects, i.e. attributes and mode(s). Furthermore, relations between various substances have been explained. The next step is to study both existence and substance in time, that is, to explicate their horizontal cross-sections. This will introduce the notions of permanence and change. Moreover, the nature of qualitative identity and qualitative difference as pertaining to a numerically identical substance in time will be explicated. Since Jain ontology avoids siding with both the ontology of absolute permanence/identity and the ontology of absolute change/difference, it is here vital to ask two questions. First, which aspects of existence are changing and which remain the same, and second, in what way does this dynamic relate to the substance-attribute-mode structure. Moreover, these two questions may be rephrased in order to address the concepts of identity and difference. Which aspects of substances remain qualitatively identical and which qualitatively differ in time? The examination of both the temporal natures of existence and substance will shed additional light on the relationship between the two.

After introducing the terms substance and existence (explicated above), Umāsvāti continues with the definition of existence (Skt. sat) in sūtra 5.29. He holds it to be three-fold. "Existence is joined with origination, cessation and

\footnotetext{
${ }^{24}$ limgehim jehị̣ davvam jīvamajīvam ca havadi viṇnādam / te'tabbhāvavisiț̣̂ā muttāmuttā guṇā neya $\bar{a} / /$
} 
persistence" 25 (Ts 5.29). What there is, is characterized by change (i.e. origination and cessation) and stability (i.e. persistence). This implies that according to Jain doctrine, the model of persistence through change may function as a universal model, i.e. a model pertaining to the whole of existence. Persistence (Skt. dhrauvya) is the lasting or enduring aspect of existence, which means the Jain model of reality cannot be reduced to one of continuous origination and cessation of phenomena, devoid of a stable underlying substratum. In line with this, Kundakunda maintains that origination and destruction can only occur on the basis of something persistent. It is impossible for them to take place independently of a permanent foundation which persists through changes. "Production is not deprived of destruction and neither is destruction deprived of (being with) production. Moreover, origination and destruction are not without a persistent object. ${ }^{26}$ (PS II.8) Not only is it asserted that origination and destruction are not deprived of each other, but also that none of them is possible without a continual base upon which to occur. Origination and cessation therefore occur on a permanent foundation. It may thus be deduced that in accordance with Jainism, origination (Skt. utpāda) is never a creatio ex nihilo but merely a taking up of a new form and, similarly, cessation (Skt. vyaya) is never a complete vanishing but merely a disappearance of an old form.

The persistent aspect of existence is referred to in $T s 5.30$ where Umāsvāti defines what being eternal entails. "Eternal is the imperishable in its nature." ${ }^{27}$ As indicated above, the ground of change is that which is imperishable. An existent in time thus remains qualitatively identical despite simultaneously going through qualitative change. It is therefore both qualitatively identical and qualitatively different at distinct moments in time. This analysis of reality thus proposes change to be some form of transformation as opposed to a radical beginning of something entirely new or a radical ending with nothing left behind. Existents persevere through transformations, which manifest as originations of new forms and cessations of past forms.

The question of the frequency of their changing, however, remains. Does change happen only occasionally or does it occur regularly? Moreover, if it takes

\footnotetext{
${ }^{25}$ utpādavyayadhrauvyayuktam sat / The past passive participle yukta may also be translated as "connected to," "coupled with," "engaged in," "endowed with," "accompanied with," "possessed of" etc.

${ }^{26}$ ṇa bhavo bhangavihīno bhango vā ṇatthi sambhavavihịno / uppādo vi ya bhañgo ṇa viṇa dhovveṇa atthena //

${ }^{27}$ tadbhāvāvyayam nityam /
} 
place regularly, is this regularity momentary or marked by some other time-unit? Kundakunda explains: "In the world, being the source of momentary destruction, nothing is produced (from), nor comes to, nothing. What is production, that is disappearance. Birth and disappearance are therefore different" ${ }^{\prime 28}$ (PS II.27). Once again he highlights that origination and destruction are not absolute in nature. $\mathrm{He}$ also indicates that change happens momentarily and additionally draws attention to a logical consequence of this occurrence, namely origination and cessation being exclusive of one another. The occurrence of one implies the loss of the other since in a particular moment only one may prevail. This remains compatible with their not being deprived of each other, since one may not arise without the loss of the other. It is this succession of origination and cessation that occurs momentarily. Momentariness of transformations agrees with the Jain ontological model proposing a coordinative relationship between permanence and change. For permanence and change to be considered coordinated, it not only follows that the permanent aspects of reality must be changing but that they are, in fact, incessantly doing so. In other words, change must be a constant inherent feature of the permanent principle.

The next step is to examine how all the three aspects of existence, namely origination, persistence and cessation, feature in substance. Gätha 10 of Kundakunda's Pañcāstikāyasāra articulates the meaning of substance with a reference to them: "Whatever is ... conjoined with origination, cessation and persistency ... is substance." ${ }^{29}$ This illustration of substance agrees with the Sanskrit word for substance, i.e. dravya, being a nominal derivative from the verbal root $\sqrt{ } d r u-$, meaning "to flow," "to flee," "to run," "to become fluid." Substance is thus something that persists through perpetual change. Umāsvāti terms this kind of changing persistence parināma, i.e. transformation.

He claims it to be the very nature of substance: "The nature of that (i.e. substance) is transformation" ${ }^{30}$ (Ts 5.41). Kundakunda agrees: "They say a substance is that which is conjoined with origination, cessation and persistency,

\footnotetext{
${ }^{28}$ jāyadi ṇeva ṇa ṇassadi khaṇabhangasamubbhave jaṇe kō / jo hi bhavo so vilao sambhavavilaya tti te nānāa //

${ }^{29}$ davvaị ... uppādavvayadhuvattasamjuttam / ...

${ }^{30}$ tadbhāvah parị̄āmah /
} 
without leaving its nature, endowed with attribute(s) and accompanied by mode(s) ${ }^{\text {31 }}$ (Ps II.3).

It is explained that substance is conjoined with origination, cessation and persistency, namely the very characteristics of existence. How then are substance and existence related? Is it safe to assume that since origination, decay and persistence are explicated as the essential constituents of existence they must characterize substance also, substance being in some fundamental way related to existence? Kundakunda holds that the relationship between substance and existence is the following: "The nature of existence is indeed the own-nature of substance with attributes (and) its own various modes, (which are) for all time having origination, cessation and persistency" ${ }^{\prime 32}$ (PS II.4). The temporal dynamics of existence and substance therefore prove to be uniform since the nature of existence is the very own-nature of substance.

Textual analysis therefore supports the notion of substance being that which is characterized by existence in the sense that the two share the same natures. This is the second interpretation proposed at the beginning of this paper. Bimal Krishna Matilal sums up the substance-existence quandary: "The Jainas ... identify the notion of 'it is' or 'it exists' with that of substance, and they then explain that 'it is' means that it is endowed with the triple character of origin, decay and stability" (Matilal 1977, 100). However, this notion is perfectly compatible with the first interpretation according to which everything that exists is substantial in nature. Kundakunda refers to objects in the following manner: "An object is made up of substances, which are described (as) having the character of attributes and with which, moreover, are modes" ${ }^{\prime 33}$ (PS II.1). This is paraphrased earlier in the text: “... An existent object abides in substance(s), attributes and modes" ${ }^{34}$ (PS I.10). Every existing object is therefore expressed as substance. This means that both of the interpretations may be taken as correct. The nature of existence is persistency through change and since existence is the own-nature of substance, persistency through change is also characteristic of substance. This is furthermore true for

\footnotetext{
${ }^{31}$ apariccattasahāveṇuppādavvayadhuvattasamjuttam / guṇavam ca sapajjāyam jam tam davvam ti vuccamti //

32 sabbhāvo hi sahāvo guṇehim saha pajjaehịn cittehim / davvassa savvakālam uppādavvayadhuvattehim //

${ }_{33}$ attho khalu davvamao davvāni guṇappagāṇi bhaṇidāṇi / tehim puno pajjāyā ... // It should here be noted that Jainism is a realist school of thought.

34 ... davvagunapajjayattho attho atthittanivvatto //
} 
every existing object which is necessarily expressed through the substanceattribute-mode structure.

It has so far been clarified that substances are constituted by general characteristics which are attributes, and specific characteristics which are modes. It has furthermore been stated that substances are that which is permanent and persists through change. This is the identity aspect of reality (cf. Ss 308). What then of attributes and modes? Which of them are persistent and which are momentarily changing? It could be deduced from the explication of their functions above that attributes as the general characteristics of substances must co-exist with the substances they characterize. This would imply that they are, like substances, permanent and remain identical through time. Modes, however, as particular manifestations of attributes and thus specific characteristics of substances could then potentially be changing. Kundakunda supports this presumption: "Origination, continuity and destruction are in modes" 35 (PS II.9). Modes are the changing aspects of substances. However, how does this relate to the above-quoted gāth $\bar{a}$ which maintained that there may be no substance without mode? It has been stated that substances may never be deprived of a mode as such and in that sense modes are essential to them. Nevertheless, single, particular modes are not essential but accidental characteristics of substances. They are lost every moment and substance in no way partakes in that loss. Furthermore, at a specific moment of its occurence, a particular mode is also always a manifestation of the permanent base upon which it occurs. The permanent foundations supporting modes persist through the changing of their accidental modes. It is perhaps in this way that Kundakunda claims that not only origination and destruction, but also continuity takes place in modes. ${ }^{36}$ Substances and their attributes therefore maintain their identity whereas modes are different in each moment of time. It may thus be deduced that modes of a single substance are not only many but potentially infinite (cf. Ps I.49).

According to the Jain theory of reality, each of the many existing objects is therefore substantial in nature. Substances may be classified into six different kinds, however, they all have the same basic structure. All of them possess permanent general qualifiers, namely attributes, and continually changing specific qualifiers, namely modes. Substances themselves are permanent like the attributes

\footnotetext{
${ }^{35}$ uppādatthidibhañgā vijjaṃte pajjaesu ... / ...

${ }^{36}$ Bimal Krishna Matilal distinguishes between persistency which is coupled with origination and destruction on the one hand and permanence as the immutable nature of substance, which is the base for the happening of the previous three (Matilal 1977, 100).
} 
they possess. This temporal structure of substances, attributes and modes thus reflects the coordinative model of Jain ontology. This means that everything which exists is not only permanent and identical but also differs in time since the permanent base continually undergoes modal change.

\section{Abbreviations}

Ns - Niyamasāra (Kundakunda)

Pks - Pañcāstikāyasāra (Kundakunda)

Ps - Pravacanasāra (Kundakunda)

Sas - Sarvārthasiddhi (Pūjyapāda)

Ss - Samayasāra (Kundakunda)

Ts - Tattvārthasūtra (Umāsvāti)

\section{References:}

Bhattacharya, Hari Satya. 1966. Reals in the Jaina Metaphysics. Motilal Banarsidass: Delhi.

Dixit, K. K. 1971. Jaina Ontology. Ahmedabad: L. D. Institute of Indology.

Gandhi, Virchand Raghavji. 1993. Religion and Philosophy of the Jainas. Ahmedabad: Jain International.

Glasenapp, Helmuth von. 1942. The Doctrine of Karman in Jain Philosophy. Bombay: Trustees, Bai Vijibai Jivanlal Panalal Charity Fund.

— 1999. Jainism. An Indian Religion of Salvation. Motilal Banarsidass: Delhi.

Halbfass, Wilhelm. 1992. On Being and What There Is. Classical Vaiśeșika and the History of Indian Ontology. Albany, New York: SUNY Press.

Jaini, Padmanabh S. 2000. Collected Papers on Jaina Studies. Delhi: Motilal Banarsidass.

— 2001. The Jaina Path of Purification. Motilal Banarsidass: Delhi.

Jhaveri, Indukala H. 1990. The Sāmkhya-Yoga and the Jain Theories of Parināma. Ahmedabad: Gujarat University.

Johnson, Will J. 1995. Harmless Souls. Motilal Banarsidass: Delhi.

Kaṇāda. 1923. Vaiśeșika sûtras of Kanāada. Translated by Nandalal Sinha. Allahabad: Pānini Office.

Kundakunda. 1935. The Pravacana-sāra of Kunda-kunda Ācārya Together with the Commentary, Tattva-dīpikā, by Amrtacandra Sūri. Translated by Barend Faddegon. Cambridge: Cambridge University Press. 
_. 2006. Niyamasāra. Translated by Uggar Sain. New Delhi: Bharatiya Jnanpith.

_. 2008. Samayasāra Translated and edited by A. Chakravarti. Benares: Bharatiya Jnanapitha Kashi.

_. 2009. Pañcāstikāya-sāra. Translated and edited by A. Chakravarti. New Delhi: Bharatiya Jnanpith.

Long, Jeffery D. 2009. Jainism. I.B. Tauris \& Co Ltd: New York.

Matilal, Bimal Krishna. 1977. "Ontological Problems in Nyāya, Buddhism and Jainism. A Comparative Analysis.” Journal of Indian Philosophy 5: 91-105.

—. 1981. The Central Philosophy of Jainism (Anekānta-vāda). Ahmedabad: L. D. Institute of Indology.

—. 2008 Logic, Language and Reality. Motilal Banarsidass: Delhi.

Mehta, Mohan Lal. 1998. Jaina Philosophy. An Introduction. Bangalore: Bharatiya Vidya Bhavan.

Monier-Williams, Monier. 2005. A Sanskrit-English Dictionary. Delhi: Motilal Banarsidass.

Mookerjee, Satkari. 1978. The Jaina Philosophy of Non-Absolutism. Delhi: Motilal Banarsidass.

Padmarajiah, Y. J. 1963. A Comparative Study of the Jaina Theories of Reality and Knowledge. Bombay: Jain Sahitya Vikas Mandal.

Pūjyapāda. 1960. Reality. English Translation of Shri Pujyapada's Sarvarthasiddhi. Translated by S. A. Jain. Calcutta: Vira Sasana Sangha.

Ramaiah, C. 1978. The Problem of Change and Identity in Indian Philosophy. Tirupati: Sri Venkateswara University.

Schubring, Walther. 1962. The Doctrine of the Jainas. Translated by Wolfgang Beurlen. Delhi: Motilal Banarsidass.

Shaha, S. M. 1987. The Dialectic of Knowledge and Reality in Indian Philosophy. Delhi: Eastern Book Linkers.

Sogani, Kamal Chand. 1967. Ethical Doctrines in Jainism. Sholapur: Lalchand Hirachand Doshi.

Soni, Jayandra. 1991. "Dravya, Guṇa and Paryāya in Jaina Thought.” Journal of Indian Philosophy 19: 75-88.

Tukol, T. K. 1980. Compendium of Jainism. Dharwad: Karnatak University.

Umāsvāti. 2011. Tattvārtha Sūtra. That Which Is. Translated by Nathmal Tatia.

HarperCollins Publishers: San Francisco, London.

Tatia, Nathmal. 1951. Studies in Jaina Philosophy. The Modern Art Press: Calcutta.

Zydenbos, Robert J. 1983. Mokṣa in Jainism according to Umāsvāti. Wiesbaden: Franz

Steiner Verlag. 